\title{
Microcircuitry for Two Types of Achromatic Ganglion Cell in Primate Fovea
}

\author{
David J. Calkins ${ }^{1}$ and Peter Sterling ${ }^{2}$ \\ ${ }^{1}$ Department of Ophthalmology and Visual Sciences, Vanderbilt University Medical Center, Nashville, Tennessee 37232, and ${ }^{2}$ Department of Neuroscience, \\ The University of Pennsylvania Medical Center, Philadelphia, Pennsylvania 19104-6058
}

Synaptic circuits in primate fovea have been quantified for midget/parvocellular ganglion cells. Here, based on partial reconstructions from serial electron micrographs, we quantify synaptic circuits for two other types of ganglion cell: the familiar parasol/magnocellular cell and a smaller type, termed "garland." The excitatory circuits both derive from two types of OFF diffuse cone bipolar cell, DB3 and DB2, which collected unselectively from at least $6 \pm 1$ cones, including the $S$ type. Cone contacts to DB3 dendrites were usually located between neighboring triads, whereas half of the cone contacts to DB2 were triad associated. Ribbon outputs were as follows: DB3, $69 \pm 5$; DB2, $48 \pm 4$. A complete parasol cell ( $30 \mu \mathrm{m}$ dendritic field diameter) would collect from $\sim 50$ cones via $\sim 120$ bipolar and $\sim 85$ amacrine contacts; a complete garland cell $(25 \mu \mathrm{m}$ dendritic field) would collect from $\sim 40$ cones via $\sim 75$ bipolar and $\sim 145$ amacrine contacts. The bipolar types contributed differently: the parasol cell received most contacts $(60 \%)$ from DB3, whereas the garland cell received most contacts (67\%) from DB2. We hypothesize that DB3 is a transient bipolar cell and that DB2 is sustained. This would be consistent with their relative inputs to the brisk-transient (parasol) ganglion cell. The garland cell, with its high proportion of DB2 inputs plus its high proportion of amacrine synapses (70\%) and dense mosaic, might correspond to the local-edge cell in nonprimate retinas, which serves finer acuity at low temporal frequencies. The convergence of $S$ cones onto both types could contribute S-cone input for cortical areas primary visual cortex and the middle temporal area.

Key words: primate retina; ganglion cell; bipolar cell; microcircuitry; ribbon synapse; parallel pathways

\section{Introduction}

In the primate fovea, cones pack densely, thereby creating the potential for high spatial resolution (Williams, 1986). To realize this potential requires private lines: each cone contacts paired "midget" bipolar cells (ON and OFF) (Wässle et al., 1994). These contact paired midget ganglion cells (Kolb and Dekorver, 1991; Calkins et al., 1994; Silveira et al., 2004), which relay to the parvocellular $(\mathrm{P})$ lateral geniculate nucleus and thence to the primary visual cortex (V1) (Callaway, 2005). Although acuity is high, sensitivity is low, being limited at the cone outer segment by photon noise and at later stages by synaptic noise. Thus, for a center spot to modulate a midget/P cell requires $10 \%$ contrast, and a full-field stimulus requires $30 \%$ contrast (Derrington and Lennie, 1984; Purpura et al., 1988).

Fortunately, there are more sensitive pathways (Dunn and Rieke, 2006). Each cone contacts "diffuse" bipolar cells that collect from $\sim 10$ cones (Boycott and Wässle, 1991; Hopkins and

Received July 21, 2006; revised Jan. 18, 2007; accepted Feb. 6, 2007

This work was supported by National Eye Institute Grants EY12480 (D.J.C.) and EY08124 (P.S.) and by a Challenge Grant and a Wasserman Award from Research to Prevent Blindness (D.J.C.). We thank Stan Schein and Yoshihiko Tsukamoto for providing the tissue, Patricia Masarachia and Sally Shrom for sectioning and EM photography, and Sharron Fina for help with this manuscript. We are grateful to Jonathan Demb and Michael Freed for comments on this manuscript.

Correspondence should be addressed to David J. Calkins, Department of Ophthalmology and Visual Sciences, The Vanderbilt Eye Institute, Vanderbilt University Medical Center, Nashville, TN 37205. E-mail: david.j.calkins@vanderbilt.edu.

DOl:10.1523/JNEUROSCI.4739-06.2007

Copyright $\odot 2007$ Society for Neuroscience $\quad$ 0270-6474/07/272646-08\$15.00/0
Boycott, 1995, 1997; Calkins et al., 1998). Diffuse cells contact non-midget ganglion cells that relay to the magnocellular (M) lateral geniculate and thence to $\mathrm{V} 1$ and the middle temporal area (MT) (Callaway, 2005). Spatial summation of photoisomerizations across cones and transmitter quanta across synapses confers greater contrast sensitivity and faster kinetics: M cells are approximately eightfold more sensitive than $\mathrm{P}$ cells and respond to higher temporal frequencies (Derrington and Lennie, 1984; Croner et al., 1993; Frechette et al., 2005). The retinal origin of the $\mathrm{M}$ pathway was generally assigned to a single anatomical class of ganglion cell termed "parasol” (Polyak, 1941; Wässle and Boycott, 1991; Grünert et al., 1993), but there are multiple types of diffuse bipolar cell (Boycott and Wässle, 1991) with different kinetics (DeVries, 2000); furthermore, there are multiple types of non-midget ganglion cell that could project to the geniculate $\mathrm{M}$ layers (Kolb et al., 1992; Rodieck and Watanabe, 1993; Dacey et al., 2003; Calkins et al., 2005). This raises key questions regarding their synaptic circuitry.

First, given evidence from peripheral retina that diffuse cone bipolar cells DB2 and DB3 both contact the OFF parasol (Jacoby et al., 2000), what are their quantitative contributions? Second, how many bipolar synapses contact a non-midget ganglion cell? Were the ratio of bipolar to amacrine synapses as low as reported for the peripheral parasol cell (Jacoby et al., 1996; Lin et al., 2002; Marshak et al., 2002), its miniaturized counterpart in the fovea would receive very few excitatory contacts, perhaps too few given quantal fluctuation, to support the known contrast sensitivity 
(Demb et al., 2004). Third, are non-midget ganglion cells truly "achromatic," i.e., excited by all three cone types? Some studies report that parasol cells lack S-cone input (Dacey and Lee, 1994; Sun et al., 2006), whereas others find strong S-cone input to the M pathway and area MT (Seidemann et al., 1999; Chatterjee and Callaway, 2002). Finally, if the fovea contains different types of non-midget ganglion cell, as shown by Golgi staining (Polyak, 1941; Kolb et al., 1992) and retrograde labeling (Dacey et al., 2003), how does their circuitry differ? To address these questions, we quantified OFF bipolar circuits that connect foveal cones to two types of non-midget ganglion cell.

\section{Materials and Methods}

We analyzed the same foveal tissue (adult male Macaca fascicularis) as in previous studies (Tsukamoto et al., 1992; Calkins et al., 1996, 1998; Klug et al., 2003). The retina had been fixed in aldehydes by perfusion and prepared for electron microscopy. Serial sections (319) were cut vertically at $\sim 90 \mathrm{~nm}$ along the horizontal meridian $\sim 3^{\circ}$ nasal to the foveal center, corresponding to an inner segment eccentricity of $\sim 1^{\circ}$. Sections were photographed en montage at $2000-10,000 \times$ and printed with an additional magnification no less than $2.5 \times$.

We identified every ganglion cell with at least one primary dendrite in a region of retina $580-640 \mu \mathrm{m}$ nasal to the foveal center and traced them through the series as far as possible. Most were midget and blue-yellow ganglion cells whose circuitry we described previously (Calkins et al., 1994, 1996, 1998). Here, identifying new cells, we partially reconstructed three OFF broad-field ganglion cells by digitizing and stacking their profiles through the series as described in our previous studies. From each, we then traced dendrites to and fro through the series, noting each postsynaptic contact and confirming with $15,000-20,000 \times$ when necessary. When the contact was from a bipolar cell (marked by a presynaptic ribbon), we traced the presynaptic terminal back to its parent axon and reconstructed as completely as possible the entire axon terminal, noting each presynaptic ribbon. Next, identifying ganglion cell dendrites postsynaptic to these ribbon contacts, we traced them far enough to tell whether they belonged to one of the three reconstructed ganglion cells.

We chose OFF cells because, as noted below, their connections could be traced all the way back to the cones. Membrane surface area for each reconstructed dendritic tree was calculated as the sum of the perimeters of individually traced dendritic profiles multiplied by the section thickness (Calkins et al., 1994). Identifying every non-midget bipolar cell in the region of interest, we traced their axonal arbors through the series, noting every presynaptic ribbon. For some of these bipolar cells, we also traced dendritic processes back to cones and characterized the synaptic contacts. Preliminary reconstructions of several cells have been published: DB3 dendritic tree (Calkins, 2000); IPL profiles of DB2 cell 28 and DB3 cell 15 (Calkins et al., 1998); parasol dendrites (Calkins, 1999).

It is very likely that the reconstructed ganglion cell arbors were incomplete. The main reason to think so is that dendritic arbors of a given type do not simply "tile"; rather, they overlap such that, for a given cell, the somas of its nearest neighbors are located on the circle inscribing the tips of the cell in question (Dacey and Brace, 1992) (for review, see Wässle, 2004). The tips of the reconstructed dendrites did not reach this far because we could not follow processes $<0.1 \mu \mathrm{m}$ in diameter. To estimate dendritic completeness, we calculated the fraction of dendritic surface area that was missed. This calculation relied on the fact that dendritic membrane for various ganglion cell types distributes as a Gaussian (Freed et al., 1992; Kier et al., 1995) (M. A. Freed, personal communication). Thus, knowing that the distal tips reach as far as the neighboring somas, we could calculate what fraction of the surface area was recovered.

In the fovea, the size of the parasol ganglion cell dendritic field would yield a Gaussian with radius at 2 SDs of $\sim 15 \mu \mathrm{m}$ (Dacey and Petersen, 1992). Following Sterling et al. (1988), we extended the obviously truncated dendrites to the full Gaussian radius and calculated the fraction of the Gaussian occupied by these dendrites. From this fraction and the membrane surface area of the actually reconstructed dendrites beneath the Gaussian, we calculated total membrane surface area. Using the density of bipolar cell synapses from the reconstructions, we extrapolated to

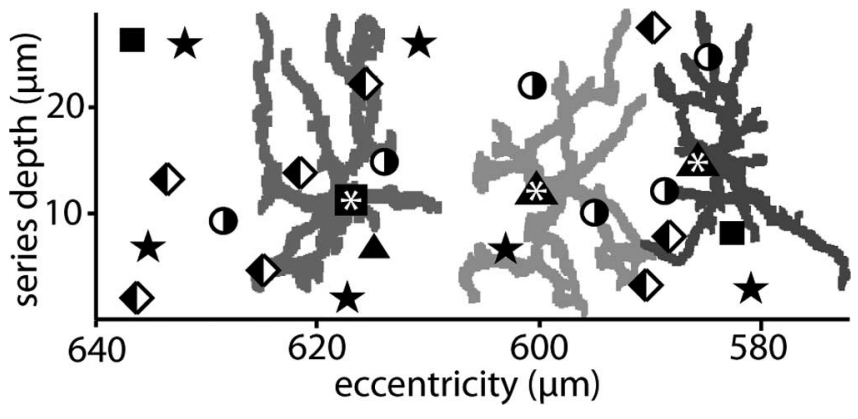

Figure 1. Tangential view of the reconstructed region. Plotted are the locations of 26 ganglion cell dendritic stalks in which they reach the OFF stratum. We could identify three parasol cells (squares) and three garland (triangles). Asterisks within larger symbols mark the locations for the three reconstructed cells, whose arbors are also shown in their actual positions. The garland arbors are displaced from their dendritic stalks compared with the parasol cell. There were also blue-yellow bistratified (half-filled circles) and unidentified cells, both bistratified (half-filled diamonds) and monostratified (stars).

obtain the total number of ribbon synapses for a complete cell. Our tracings established the number of ribbons made by each bipolar cell to each ganglion cell and allowed us to calculate how many additional DB3/ DB2 cells probably contribute. Using the number of cone inputs to the DB3 and DB2 cells and the overlap of their neighboring dendritic trees (Calkins et al., 1998, their Fig. 9) (see Fig. 7), we calculated the total convergence to each ganglion cell based on the number of new cones contributed by each additional bipolar cell. Unless indicated otherwise, statistical comparisons are given as mean $\pm \mathrm{SD}$.

Ganglion cell density was calculated using dendritic field diameter (in millimeters) as the inter-cell spacing (C) (Wässle, 2004) and assuming hexagonal packing of the mosaic, which results in a triangular sampling array (Williams, 1986). In this case, density in cells per square millimeter is calculated from the area of the triangle as $\left(2 \times 3^{-1 / 2}\right) / C^{2}$ (Merigan and Katz, 1990).

\section{Results}

\section{Non-midget ganglion cells identified}

The OFF stratum in this slab of the inner synaptic layer contained dendrites from 26 non-midget ganglion cells (Fig. 1). Three of these each sent a single stalk almost perpendicular to the plane of the retina to stratify narrowly in the inner plexiform layer at $30-50 \%$ depth. The most complete of these cells is shown with its flat arbor in Figure 2. It closely resembled the parasol ganglion cell described by Polyak (1941) and Boycott and Dowling (1969) and identified by immunocytochemistry (Grünert et al., 1993). Consistent with this, its longest reconstructed dendrites extended 15-18 $\mu \mathrm{m}$ (Fig. 1), which matches the lengths of foveal parasol dendrites measured by intracellular injections (Dacey and Petersen, 1992; Rodieck and Watanabe, 1993).

We traced the other two cells far enough to identify their flat dendritic arbors over the cell body and to identify 14 and 18 bipolar contacts and 9 and 12 amacrine contacts, respectively. However, these fragments were insufficient to present as full reconstructions, so the following description rests on the most complete cell. Variability across the type obviously cannot be evaluated from this material. Conversely, we do know from many other ganglion cell reconstructions that variability within a type over a small patch of retina is negligible (Freed and Sterling, 1988; Cohen and Sterling, 1992; Calkins et al., 1994, 1998). Indeed, the ratio of bipolar to amacrine contacts for the two incomplete cells $(\sim 1.5)$ agrees with the circuitry we describe below for the reconstructed parasol cell.

Three other cells each sent a stalk that angled away from the cell body so that the dendritic arbors were displaced by $10-12$ 


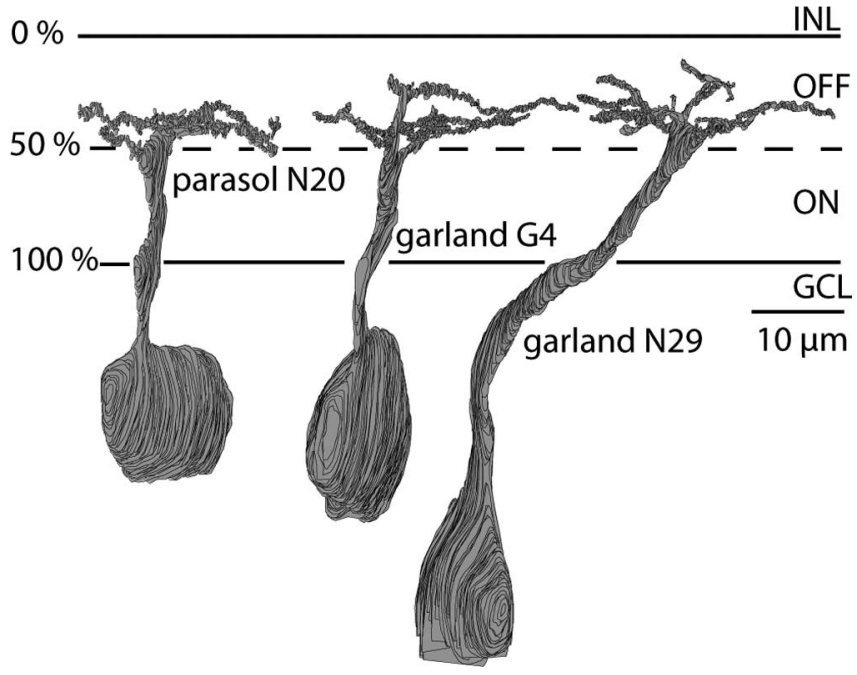

Figure 2. Radial views of reconstructed parasol and garland cells. The parasol dendrites stratify narrowly ( $30-50 \%$ level of inner plexiform layer) almost perpendicular to the cell body, whereas the garland dendrites stratify more broadly in the $0 \mathrm{FF}$ stratum and are displaced from the cell body. Each cell has been rotated independently around its vertical axis without changing the level of stratification to optimally display dendritic complexity. The garland vertical axes are in their actual position with respect to one another; their overlap is better assessed in Figure 1. INL, Inner nuclear layer; GCL, ganglion cell layer.

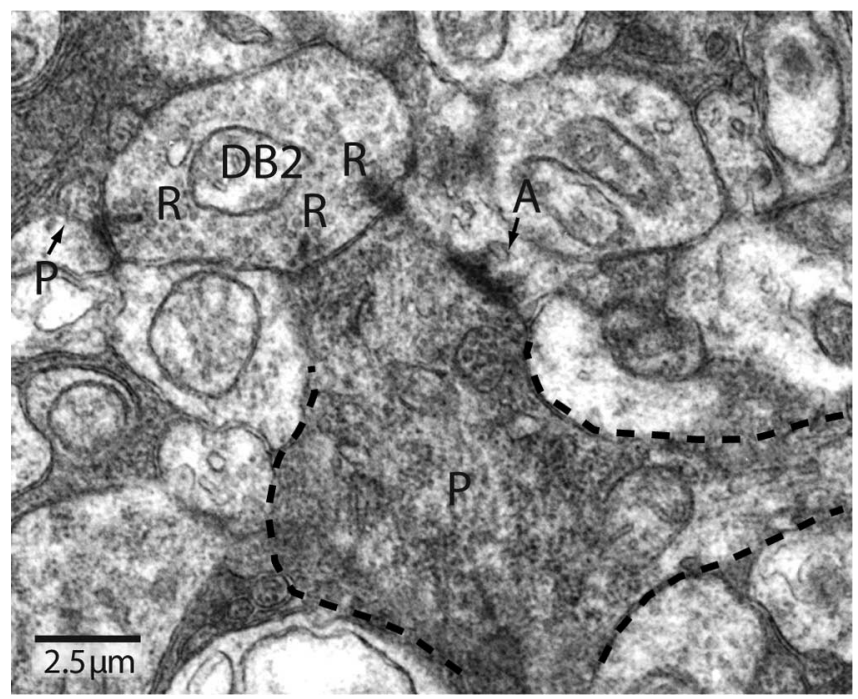

Figure 3. Identification of synaptic contacts to a parasol ganglion cell. Parasol dendrite (P) receiving three ribbon contacts (R) from a DB2 axon terminal (cell 28 in Fig. 4) and a conventional contact (arrow) from an amacrine cell process (A).

$\mu \mathrm{m}$. The stalk ramified into fine, "knotty" dendrites that distributed diffusely at a depth of $10-40 \%$ (Fig. 2). The longest dendrites in these arbors extended $12-15 \mu \mathrm{m}$, their lengths equaling the distance between the somas of their neighbors (Fig. 1). Thus, these cells appeared to be more nearly complete than the parasol cell and also to be present at somewhat greater density. Two of the cells were reconstructed in detail to identify their ribbon contacts from bipolar cells and conventional contacts from amacrine cells (Fig. 3).

What to call these ganglion cells, which are broader field than the midget cells but narrower than the standard parasol cells? Non-midget types other than parasol have been observed in primate fovea by Golgi impregnation (Polyak, 1941; Boycott and Dowling, 1969; Kolb et al., 1992) and beyond the fovea by intra-

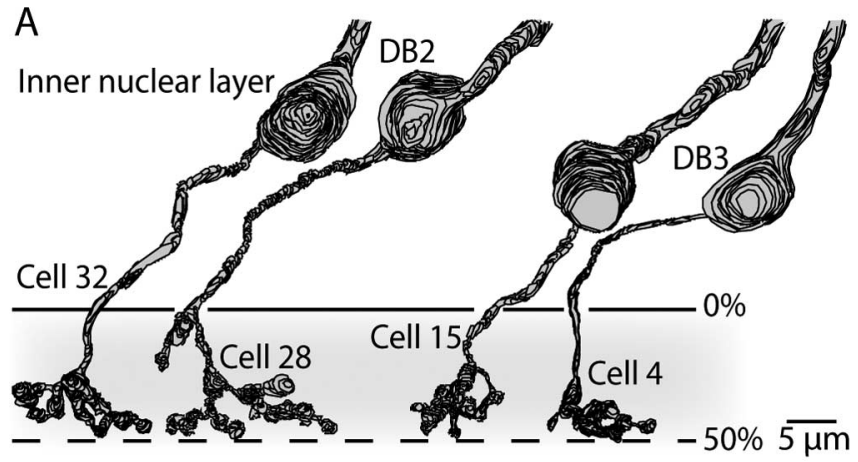

B
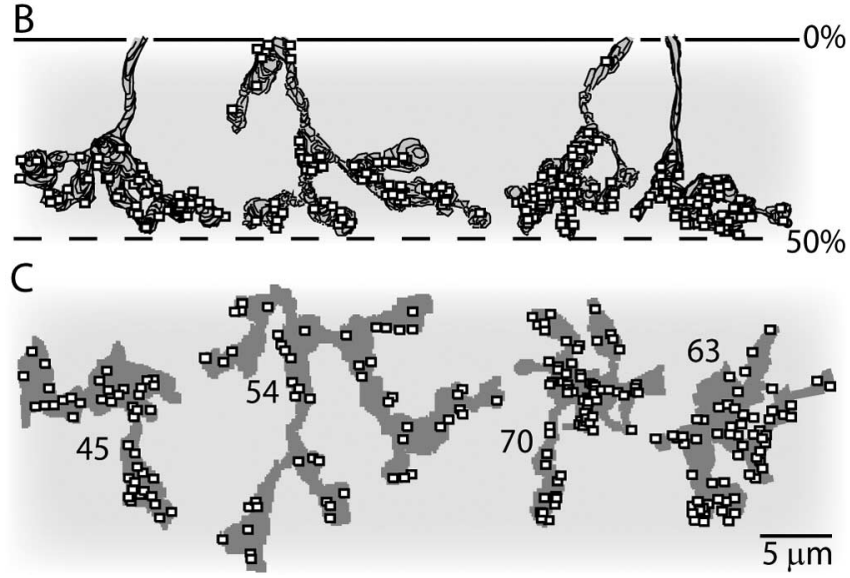

Figure 4. Stratification and axon arbors from diffuse bipolar types DB2 and DB3. $\boldsymbol{A}$, Radial view shows DB2 somas higher in the nuclear layer and broader axonal arbors. $\boldsymbol{B}$, Same terminals at higher magnification show DB3 with more synaptic ribbons. In tangential view of same terminals $(\boldsymbol{C}), \mathrm{DB} 3$ ribbons are more numerous and cluster more densely. Some ribbons overlap. The scale is the same for $\boldsymbol{B}$ and $\boldsymbol{C}$.

cellular injection (Rodieck and Watanabe, 1993; Dacey et al., 2003; Yamada et al., 2005). Because cell morphology changes rapidly near the fovea with small shifts in eccentricity, we remain uncertain as to how these partially reconstructed non-parasol cells correspond to the descriptions from light microscopy. For example, although bearing some resemblance to the "thorny" ganglion cells identified recently in primate retina (Dacey et al., 2003), the thorny cells are much broader field than the parasol cell at a given eccentricity (compare with Dacey and Petersen, 1992), whereas the present cells are narrower than the parasol. Nevertheless, because we need to call them something and they somewhat resemble the "garland" cell of Polyak (1941) and Boycott and Dowling (1969), we tentatively call them that. The next step was to identify all of the synapses contacting both types of ganglion cell and trace them to their cells of origin.

Two types of diffuse bipolar cell contact both the parasol and the garland cells

We reconstructed terminals of four bipolar cells comprising two types, DB2 and DB3 (Fig. 4) (Boycott and Wässle, 1991). Both types were found previously to contact OFF dendrites of the blueyellow ganglion cell (Calkins et al., 1998). The DB2 somas occupied the middle of the inner nuclear layer; their axon arbors ramified diffusely at 10-50\% depth and formed 45 and 54 ribbons. The DB3 somas lay deeper; their axon arbors were more compact and more narrowly stratified at $35-50 \%$ depth. These formed 70 and 63 ribbons.

To further quantify these two types of axon terminal, we 


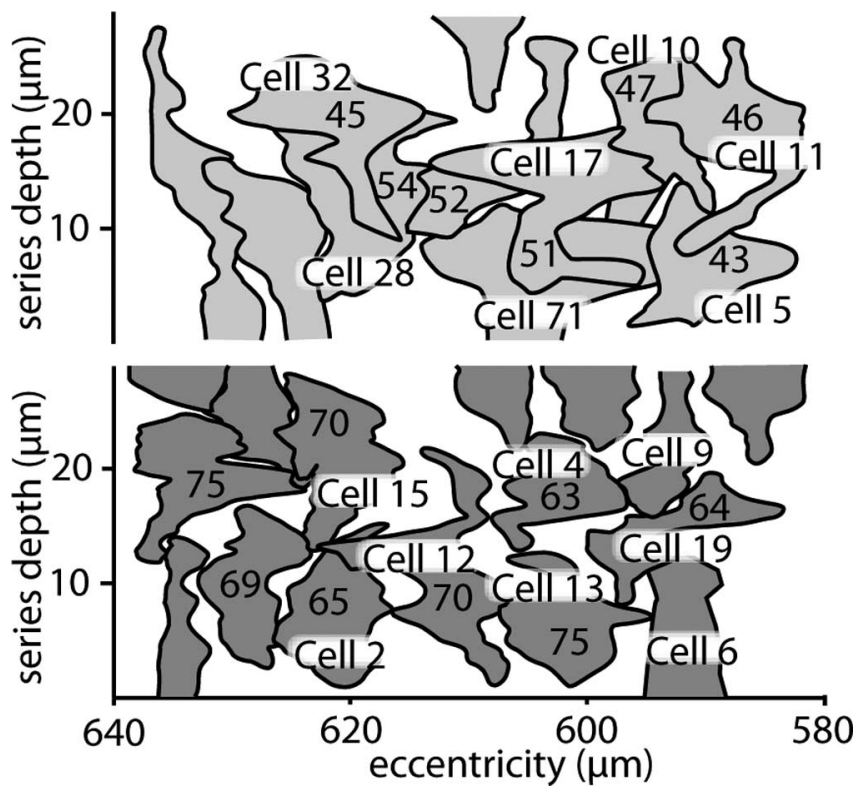

Figure 5. Tangential view of DB2 (top) and DB3 (bottom) axon arbors. The perimeter of neighboring DB2 and DB3 axon arbors indicate breadth of ramification; depth of terminals has been collapsed into a single plane. Numbers of synaptic ribbons are indicated for terminals complete within the series. Terminals contacting the parasol or garland cells are labeled, as is DB3 cell 4 from Figure 4. Scale is the same as in Figure 1.

traced every bipolar cell axon arbor that terminated at this level (Fig. 5). These were classified as DB2 or DB3 based on their stratification, number of ribbons, or contacts with cones (see below). There were 11 DB2 arbors, of which seven were completely contained within the series. These expressed $48 \pm 4$ ribbons (mean $\pm \mathrm{SD}$ ). There were 16 DB3 arbors, of which eight were complete, and these each expressed $69 \pm 5$ ribbons. Although DB3 had $>40 \%$ more ribbons than DB2, its "footprint" was smaller (DB2, $85 \pm 22 \mu \mathrm{m}^{2}$; DB3, $67 \pm 15 \mu \mathrm{m}^{2}$ ), so DB3 showed nearly twice the density of ribbons per retinal area (1.1 vs 0.6 ribbons $/ \mu \mathrm{m}^{2}$ ). Thus, DB3 cells outnumbered DB2 cells by a factor of 1.5, and each provided more total ribbons by a factor of 1.4, so the DB3 array provided 2.1-fold more ribbon outputs.

Next, we traced the dendrites of these two bipolar types back to their connections with cone terminals (Fig. 6). Dendrites of DB2 made basal contacts that could be either triad associated or non-triad associated, as reported for peripheral DB2 cells (Hopkins and Boycott, 1995, 1997). Dendrites of DB3 made basal contacts that were all non-triad associated, thus differing from peripheral DB3 cells that are mostly triad associated (Hopkins and Boycott, 1995). The DB2 and DB3 cells were traced to at least five to eight cones, including $S$ and $\mathrm{M} / \mathrm{L}$ cones (Fig. 7), but complete DB2 and DB3 cells are known to collect from 7-12 cones, both outside the fovea (Boycott and Wässle, 1991; Hopkins and Boycott, 1995, 1997) and within (Calkins et al., 1998).

The DB2 cells in Figure 7 collected $16-28$ contacts $(20 \pm 7$ per cell), yielding $3.2 \pm 0.3$ contacts per cone. Of these, $8 \pm 1$ contacts per cell were triad associated, i.e., nearer one ribbon than the others, and $12 \pm 6$ were non-triad associated. The DB3 cells received $21-31$ contacts ( $25 \pm 6$ contacts per cell), yielding $4.6 \pm$ 0.3 contacts per cone. Approximately $65 \%$ of non-triadassociated contacts lie between two triads (Fig. 6) (Calkins et al., 1996; Chun et al., 1996) and would receive quanta from both ribbons (DeVries et al., 2006) (K. Klug, S. Schein, and P. Sterling, unpublished observation). Thus, a DB2 cell would receive at its
20 contacts $\sim 32$ quanta, whereas a DB3 cell would receive at its 25 contacts $\sim 42$ quanta/cell. Given $1.5 \times$ more DB3 cells, the array would receive approximately twofold more quanta than the DB2 array.

For the DB2 and DB3 cells in Figure 7, if an S cone was within reach of the dendritic tree, contact was made. This was so for a single DB2 cell, which received one non-triad-associated contact from an $\mathrm{S}$ cone, and for all three DB3 cells, which each received $3 \pm 2$ non-triad-associated contacts, from single $S$ cones. For all but one DB2/DB3 cell in Figure 7, the small number of S-cone contacts (one to two per bipolar cell) can be explained by the peripheral location of the $S$ cone over the tree. In contrast, DB3 cell 3 in Figure 7 received 6 of its 24 non-triad-associated contacts from an $\mathrm{S}$ cone nearer the center of its dendritic arbor. So the strength of the $S$ input to each diffuse cell apparently reflects the density of dendrites beneath the cone (compare DB2 cell 0 with DB3 cell 3).

\section{Bipolar contacts to parasol and garland cells}

The reconstructed parasol cell received 85 ribbon contacts: 27 DB2, 40 DB3, and 18 unidentified (Fig. 8, top). Six identified bipolar axons converged onto this cell, each contributing 1-17 (DB2) or 7-17 (DB3) contacts. One dendrite collected a cluster of 10 ribbon contacts from the same bipolar terminal, not identified as to type (top right dendrite). Thus, at least seven bipolar cells converged onto this cell, carrying signals from at least the 20 cones identified contacting their reconstructed dendritic arbors (Figs. 6, 7).

One reconstructed garland cell (cell G4) received 65 ribbon contacts: 35 DB2, 17 DB3, and 13 unidentified. Nine identified bipolar cells converged onto this cell: five DB2, each contributing five to eight contacts, and four DB3, each contributing two to seven contacts. We did not quantify their cone inputs. A second reconstructed garland cell (cell N29) received 52 ribbon synapses, but, being beyond the region of the reconstructed bipolar cells, these could not be identified as to type. Thus, the parasol and garland cells both had substantial input from the same bipolar types, but in quite different proportions of the known bipolar inputs: 60\% DB3 for the parasol, and the reverse, $67 \%$ DB2, for the garland cell. For the garland cell, the contacts from each bipolar were also more evenly distributed among the cells.

\section{Amacrine contacts to parasol and garland cells}

The parasol cell received 62 amacrine contacts. These distributed evenly along the dendrites, interspersing with the ribbon contacts (Fig. 8, bottom). Amacrine contacts comprised less than half of the total contacts $(42 \%)$. This differs from the peripheral parasol cell in which the fraction is reported to be $87 \%$ (Marshak et al., 2002). The garland cell G4 received 124 amacrine contacts, and the other (N29) received 117 amacrine contacts (Fig. 8, bottom). These contacts were also distributed evenly along the dendrites and interspersed with ribbon contacts. For both cells, amacrine contacts comprised approximately two-thirds of the total.

\section{Estimating the full circuits}

The partially reconstructed dendritic arbors had the following membrane surface areas: $165 \mu \mathrm{m}^{2}$ for the parasol cell and 178 and $175 \mu \mathrm{m}^{2}$ for the two garland cells (Fig. 8). The calculated total synaptic densities were similar: 89 contacts $/ 100 \mu \mathrm{m}^{2}$ (parasol), and 106 and 97 contacts $/ 100 \mu \mathrm{m}^{2}$ (garlands). The bipolar contact densities differed: 52 ribbons $/ 100 \mu \mathrm{m}^{2}$ (parasol) cell, but only 37 and 30 ribbons $/ 100 \mu \mathrm{m}^{2}$ for the two garland cells. It seems likely that parasol and garland cells would share input from 
the same bipolar terminals, but, because the reconstructed arbors did not overlap (Fig. 1), we could not determine this for certain.

As noted, the reconstructions shown in Figures 2 and 8 certainly omit distal dendritic segments, because ganglion cell dendritic fields in general (Wässle, 2004) and parasol cells in particular (Dacey and Brace, 1992) reach the somas of their nearest neighbors. Based on this point, we calculate that the full dendritic field of the parasol cell would be $\sim 30 \mu \mathrm{m}$ diameter. The reconstructed dendritic membrane is $\sim 70 \%$ complete (see Materials and Methods), so the full cell would have a membrane surface area of $\sim 235 \mu \mathrm{m}^{2}$. Based on this surface area and the measured synaptic densities, a complete parasol cell should receive $\sim 120$ bipolar contacts and $\sim 85$ amacrine synapses. Based on the number of converging bipolar cells and the number of cones converging to each (see Materials and Methods), these synapses would represent some 50 cones. By comparison, the parasol dendritic fields measured by Grünert et al. (1993) were 37-38 $\mu \mathrm{m}$ across and were estimated to receive 30-50 cones. The match seems good, assuming that their sample was slightly more eccentric, in which the dendritic fields are somewhat larger and the cone density somewhat lower.

By the same reasoning, we calculate that a complete garland cell dendritic field would be $\sim 25 \mu \mathrm{m}$ diameter and that their reconstructed dendritic membranes were $\sim 85 \%$ complete (G4) and $80 \%$ complete (N29). A complete garland cell would have a total membrane area of $\sim 215 \mu \mathrm{m}^{2}$ and should receive $\sim 75$ bipolar contacts and $\sim 145$ amacrine contacts, representing $\sim 45$ cones.

\section{Discussion}

In agreement with studies on peripheral retina (Jacoby et al., 2000), we found that the foveal OFF parasol cell collects from two types of diffuse bipolar cell. DB3 predominates, providing $60 \%$ of the ribbon contacts, with $40 \%$ from DB2. Because the parasol cell is functionally brisk transient (Dacey and Lee, 1994; Frechette et al. 2005), this suggests, prima facie, that DB3 is a brisk-transient bipolar cell.

This hypothesis is consistent with the following points: (1) in cat, the brisk-transient ganglion cell also receives predominantly from one type of bipolar cell (Freed and Sterling, 1988; Kolb and Nelson, 1993) and that type gives a transient voltage response (Nelson and Kolb, 1983) and transient quantal release (Freed, 2000a); (2) the transient bipolar type in cat expresses the most total ribbon outputs (Cohen and Sterling, 1990) and contacts other ganglion cell types (Cohen and Sterling 1992); (3) DB3 resembles this pattern, expressing more total ribbons than DB2 and contributing contacts to at least two other ganglion cell types, the garland cell and the small, bistratified cell (Calkins et al., 1998); (4) non-triad-associated dendritic contacts are generally located between cone ribbons and should receive quanta from both (DeVries et al., 2006) (Klug, Sterling, and Schein, unpublished observation). This implies that the DB3 array would receive quanta at twice the rate of DB2 (see Results). Thus, the DB3 array should collect information at a higher rate than DB2, consistent with its greater number of output synapses, and yield a higher temporal bandwidth. DB2, with its lower input rate and fewer outputs, is likely to release quanta tonically and transmit lower temporal frequencies (Freed, 2000b). Transmission of lowfrequency components might be important for foveal parasol cells because eye moments that steady the fovea on a target reduce the range of temporal frequencies in the fovea (Eckert and Buchsbaum, 1993).

It was somewhat surprising to discover an additional type of achromatic ganglion cell that distributes more densely than the parasol cell. Confidence that the garland cell is distinct from the parasol cell rests on these points: (1) it shows a different dendritic morphology, broader stratification, narrower dendritic field, and less total dendritic membrane (Figs. 1, 2, 8); (2) it receives fewer bipolar contacts, with twice as many DB2 contacts as DB3 that would provide more sustained than transient contacts, essentially the inverse of the parasol cell; and (3) it receives a threefold higher ratio of amacrine/bipolar contacts than the parasol cell (2.0 vs 0.7 ).

We cannot confidently state the garland cell density based on so few cells. However, knowing its dendritic extent, that its nearest neighbors should fall on the circle circumscribing the dendrites (Wässle, 2004) and assuming a hexagonal sampling array 


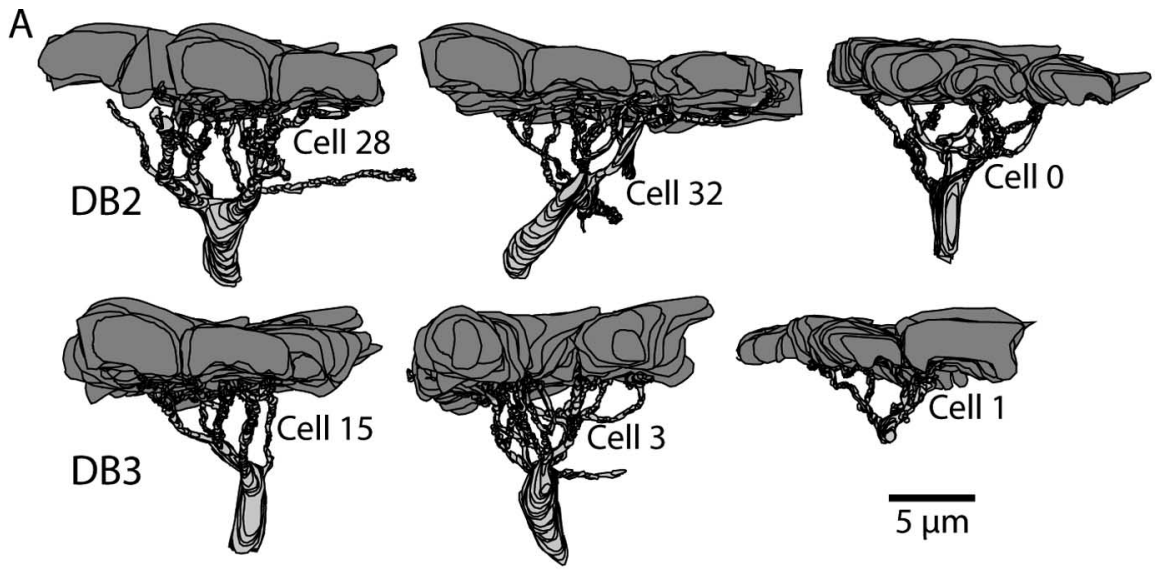

$B$

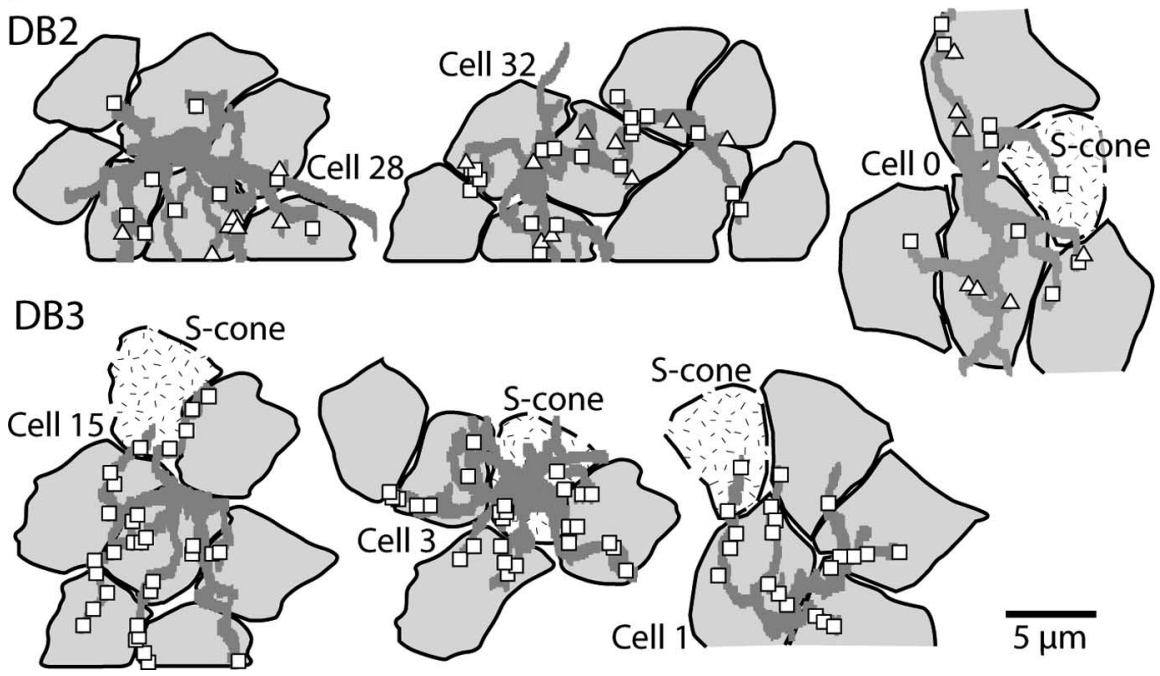

Figure 7. $\mathrm{DB} 2$ and $\mathrm{DB} 3$ cells collect indiscriminately from all cones within reach. $\boldsymbol{A}$, Reconstructed dendritic trees (radial view) of DB2 and DB3 cells, each contacted by at least five to eight cones. Orientation is the same as in Figure 4 . $B$, Reconstructed dendritic trees (tangential view) from the cells in Figure 6 showing profiles of overlying cone terminals. DB2 cells receive cone contacts from basal junctions, both triad associated (triangles) and non-triad associated (squares). DB3 cells receive contacts solely from nontriad-associated basal junctions. Each cell collects from all cones within reach, including S. Some contacts overlap.

receives a nearly threefold higher proportion of amacrine contacts, which are likely to be inhibitory. In other mammals, low information rates and strong inhibitory input are characteristic of "local-edge" cells (Koch et al., 2004, 2006; van Wyk et al., 2006). Furthermore, because in other mammals local-edge cells are the smallest cells, they are also among the most numerous and are thought to convey spatial acuity at low temporal frequencies (van Wyk et al., 2006). Thus, we suggest that the garland type corresponds to the local-edge type described in other mammals and that it serves a similar function. Another possible comparison would be to the brisksustained ganglion cell, but that type in the cat central area has (1) more bipolar than amacrine synapses (Cohen and Sterling, 1992 ) and (2) more transient bipolar synapses than sustained, the reverse of what we find for garland cells.

Thus, the greater contrast sensitivity of the M pathway (see Introduction) might rest on several ganglion cell types, one with relatively poor spatial resolution but faster kinetics (the parasol/brisktransient) and another with better spatial resolution but slower kinetics (the garland/local-edge). These types might underlie the two distinct mechanisms for motion sensitivity (one selective for high and the other for low temporal frequencies) identified psychophysically (Watson and Robson, 1981). That the local-edge type has so far escaped electrophysiological notice in primate may not be too surprising. Local-edge cells were rarely recorded in other mammals in vivo because the cells are small and the axons are fine (for review, see Troy and Shou, 2002).

(Wässle and Boycott, 1991), the density ought to be $\sim 7000$ cells/ $\mathrm{mm}^{2}$ (see Materials and Methods). By the same reasoning, OFF parasol densities at this locus ought to be $\sim 5000$ cells $/ \mathrm{mm}^{2}$. The OFF parasols are more numerous than ON, possibly by $1.8 \times$ (averaging data from Dacey and Petersen, 1992; Chichilnisky and Kalmar, 2002). This implies an ON density of $\sim 2800$ cells $/ \mathrm{mm}^{2}$ and a total for all parasols of 7800 cells $/ \mathrm{mm}^{2}$. Using the cone density in our material $\left(26,500 / \mathrm{mm}^{2}\right)$ (Ahmad et al., 2003) and assuming three ganglion cells per cone (Wässle et al., 1990), this would represent $9.8 \%$ of all ganglion cells. This is in good agreement with the upper bound of $8 \%$ for parasols predicted from immunocytochemical labeling (Grünert et al., 1993).

\section{Possible functional differences}

How the parasol and garland cells differ functionally remains to be determined, but here is a speculation. The parasol cell, as discussed above, expresses circuitry suited to its established "brisk-transient" function, albeit with some sustained input to capture the lower temporal frequencies contained in natural images that are stabilized on the fovea.

The garland cell expresses circuitry apparently suited to transmitting lower frequencies and lower information rates. Also, it
Only now that they can be easily recorded by patch electrodes in vitro (Koch et al., 2004; Xu et al., 2005; van Wyk et al., 2006) and by multielectrode arrays (DeVries and Baylor, 1997; DeVries, 1999; Koch et al., 2006) are they getting the attention warranted by their relatively high densities.

\section{Diffuse bipolar types distribute S-cone signals to multiple ganglion cell types}

Another point emerging from this study is that both DB2 and DB3 cells collect indiscriminately from all cones, including $S$, as also found for DB3 cells in the marmoset (Chan et al., 2001) and for ON diffuse bipolar cells (Calkins, 2001; Lee et al., 2006). Thus, the diffuse bipolar cells convey S-cone signals to at least three types of ganglion cell: parasol, garland, and the small, bistratified cell. Because the brisk-transient (parasol) pathway projects strongly to cortical area MT, it might be an important source for the strong S-cone signals in MT (Seidemann et al., 1999; Chatterjee and Callaway, 2002), although MT apparently gets some S-cone input via P cells (Nassi et al., 2006). The central projections of the garland cell are unknown, but, if it corresponds to one of the cells identified by light microscopy that projects to the geniculate (Rodieck and Watanabe, 1993; Dacey et al., 2003; 
Calkins et al., 2005), the garland cell might also contribute to the S-cone cortical pathways.

\section{References}

Ahmad KM, Klug K, Herr S, Sterling P, Schein S (2003) Cell density ratios in a foveal patch in macaque retina. Vis Neurosci 20:189-209.

Boycott BB, Dowling JE (1969) Organization of the primate retina: light microscopy. Philos Trans R Soc Lond B Biol Sci 255:109-184.

Boycott BB, Wässle H (1991) Morphological classification of bipolar cells of the primate retina. Eur J Neurosci 3:1069-1088.

Calkins DJ (1999) Synaptic organization of cone pathways in the primate retina. In: Color vision from molecular genetics to perception (Gegenfurtner K, Sharpe L, eds), Cambridge, MA: Cambridge UP.

Calkins DJ (2000) The representation of cone signals in the primate retina. J Opt Soc Am B 17:597-606.

Calkins DJ (2001) Seeing with S cones. Prog Ret Eye Res 20:255-287.

Calkins DJ, Schein S, Tsukamoto Y, Sterling P (1994) $\mathrm{M}$ and $\mathrm{L}$ cones in macaque fovea connect to midget ganglion cells via different numbers of excitatory synapses. Nature 371:70-72.

Calkins DJ, Tsukamoto Y, Sterling P (1996) Foveal cones form basal as well as invaginating junctions with diffuse $\mathrm{ON}$ bipolar cells. Vision Res 36:3373-3381.

Calkins DJ, Tsukamoto Y, Sterling P (1998) Microcircuitry and mosaic of a blue/yellow ganglion cell in the primate retina. J Neurosci 18:3373-3385.

Calkins DJ, Sappington RM, Hendry SH (2005) Morphological identification of ganglion cells expressing the alpha subunit of type II calmodulin-dependent protein kinase in the macaque retina. J Comp Neurol 481:194-209.

Callaway EM (2005) Structure and function of parallel pathways in the primate early visual system. J Physiol (Lond) 566:13-19.

Chan TL, Martin PR, Clunas N, Grünert U (2001) Bipolar diversity in the primate retina: morphologic and immunocytochemical analysis of a new work monkey, the marmoset Callithrix jacchus. J Comp Neurol 437:219-239.

Chatterjee S, Callaway EM (2002) S cone contributions to the magnocellular visual pathway in macaque monkey. Neuron 35:1135-1146.

Chichilnisky EJ, Kalmar RS (2002) Functional asymmetries in ON and OFF ganglion cells of primate retina. J Neurosci [Erratum (2002) 22:1a] 2737-2747.

Chun MH, Grünert U, Martin PR, Wässle H (1996) The synaptic complex of cones in the fovea and in the periphery of the macaque monkey retina. Vision Res 36:3383-3395.

Cohen E, Sterling P (1990) Demonstration of cell types among cone bipolar neurons of cat retina. Philos Trans R Soc Lond B Biol Sci 330:305-321.

Cohen E, Sterling P (1992) Parallel circuits from cones to the On-beta ganglion cell. Eur J Neurosci 4:506-520.

Croner LJ, Purpura K, Kaplan E (1993) Response variability in retinal ganglion cells of primates. Proc Natl Acad Sci USA 90:8128-8130.

Dacey DM, Brace S (1992) A coupled network for parasol but not midget ganglion cells in the primate retina. Vis Neurosci 9:279-290.

Dacey DM, Lee BB (1994) The "blue-on" opponent pathway in primate retina originates from a distinct bistratified ganglion cell type. Nature 367:731-735.

Dacey DM, Petersen M (1992) Dendritic field size and morphology of midget and parasol ganglion cells of the human retina. Proc Natl Acad Sci USA 89:9666-9670.

Dacey DM, Peterson BB, Robinson FR, Gamlin PD (2003) Fireworks in the primate retina: in vitro photodynamics reveal diverse LGN-projecting ganglion cell types. Neuron 37:15-27.

Demb JB, Sterling P, Freed MA (2004) How retinal ganglion cells prevent synaptic noise from reaching the spike output. J Neurophysiol 92:2510-2519.

Derrington AM, Lennie P (1984) Spatial and temporal contrast sensitivities of neurones in lateral geniculate nucleus of macaque. J Physiol (Lond) 357:219-240.

DeVries SH (1999) Correlated firing in rabbit retinal ganglion cells. J Neurophysiol 81:908-920.

DeVries SH (2000) Bipolar cells use kainate and AMPA receptors to filter visual information into separate channels. Neuron 28:847-856.

DeVries SH, Baylor DA (1997) Mosaic arrangement of ganglion cell receptive fields in rabbit retina. J Neurophysiol 78:2048-2060.

DeVries SH, Li W, Saszik S (2006) Parallel processing in two transmitter microenvironments at the cone photoreceptor synapse. Neuron 50:735-748.

Dunn FA, Rieke F (2006) The impact of photoreceptor noise on retinal gain controls. Curr Opin Neurobiol 4:363-370.

Eckert MP, Buchsbaum G (1993) Efficient coding of natural time varying images in the early visual system. Philos Trans R Soc Lond B Biol Sci 339:385-395.

Frechette ES, Sher A, Grivich MI, Petrusca D, Litke AM, Chichilnisky EJ (2005) Fidelity of the ensemble code for visual motion in primate retina. J Neurophysiol 94:119-135.

Freed MA (2000a) Rate of quantal excitation to a retinal ganglion cell evoked by sensory input. J Neurophysiol 83:2956-2966.

Freed MA (2000b) Parallel cone bipolar pathways to ganglion cell use different rates and amplitudes of quantal excitation. J Neurosci 20:3956-3963. 
Freed MA, Sterling P (1988) The ON-alpha ganglion cell of the cat retina and its presynaptic cell types. J Neurosci 8:2303-2320.

Freed MA, Smith RG, Sterling P (1992) Computational model of the onalpha ganglion cell receptive field based on bipolar circuitry. Proc Natl Acad Sci USA 89:236-240.

Grünert U, Greferath U, Boycott BB, Wässle H (1993) Parasol (P $\alpha)$ ganglion-cells of the primate fovea: Immunocytochemical staining with antibodies against $\mathrm{GABA}_{\mathrm{A}}$ receptors. Vision Res 33:1-14.

Hopkins JM, Boycott BB (1995) Synapses between cones and diffuse bipolar cells of a primate retina. J Neurocytol 24:680-694.

Hopkins JM, Boycott BB (1997) The cone synapses of cone bipolar cells of primate retina. J Neurocytol 26:313-325.

Jacoby R, Stafford D, Kouyama N, Marshak D (1996) Synaptic inputs to ON parasol ganglion cells in the primate retina. J Neurosci 16:8041-8056.

Jacoby RA, Wiechmann AF, Amara SG, Leighton BH, Marshak DW (2000) Diffuse bipolar cells provide input to OFF parasol ganglion cells in the macaque retina. J Comp Neurol 416:6-18.

Kier CK, Buchsbaum G, Sterling P (1995) How retinal microcircuits scale for ganglion cells of different size. J Neurosci 15:7673-7683.

Klug K, Herr S, Ngo I-T, Sterling P, Schein S (2003) Macaque retina contains an S-cone OFF midget pathway. J Neurosci 23:9881-9887.

Koch K, McLean J, Berry M, Sterling P, Balasubramanian V, Freed MA (2004) Efficiency of information transmission by retinal ganglion cells. Curr Biol 14:1523-1530.

Koch K, McLean J, Segev R, Freed MA, Berry MJII, Balasubramanian V, Sterling P (2006) How much the eye tells the brain. Curr Biol 16:1428-1434.

Kolb H, Dekorver L (1991) Midget ganglion cells of the parafovea of the human retina: a study by electron microscopy and serial section reconstructions. J Comp Neurol 303:617-636.

Kolb H, Nelson R (1993) OFF-alpha and OFF-beta ganglion cells in cat retina: II. Neural circuitry as revealed by electron microscopy of HRP stains. J Comp Neurol 329:85-110.

Kolb H, Linberg KA, Fisher SK (1992) Neurons of the human retina: a Golgi study. J Comp Neurol 318:147-187.

Lee SC, Jusuf PR, Grünert U (2006) S-cone connections of the diffuse bipolar cell type DB6 in macaque monkey retina. J Comp Neurol 474:353-363.

Lin B, Martin PR, Grünert U (2002) Expression and distribution of ionotropic glutamate receptor subunits on parasol ganglion cells in the primate retina. Vis Neurosci 19:453-465.

Marshak DW, Yamada ES, Bordt AS, Perryman WC (2002) Synaptic input to an ON parasol ganglion cell in the macaque retina: a serial section analysis. Vis Neurosci 19:299-305.

Merigan WH, Katz LM (1990) Spatial resolution across the macaque retina. Vision Res 30:985-991.

Nassi JJ, Lyon DC, Callaway EM (2006) The parvocellular LGN provides a robust disynaptic input to the visual motion area MT. Neuron 50:319-327.
Nelson R, Kolb H (1983) Synaptic patterns and response properties of bipolar and ganglion cells in the cat retina. Vision Res 23:1183-1195.

Polyak SL (1941) The retina. Chicago: University of Chicago.

Purpura K, Kaplan E, Shapley RM (1988) Background light and the contrast gain of primate $\mathrm{P}$ and $\mathrm{M}$ retinal ganglion cells. Proc Natl Acad Sci USA 85:4534-4537.

Rodieck RW, Watanabe M (1993) Survey of the morphology of macaque retinal ganglion cells that project to the pretectum, superior colliculus, and parvicellular laminae of the lateral geniculate nucleus. J Comp Neurol 338:289-303.

Seidemann E, Poirson AB, Wandell BA, Newsome WT (1999) Color signals in area MT of the macaque monkey. Neuron 24:911-917.

Silveira LC, Saito CA, Lee BB, Kremers J, da Silva FHL, Kilavik BE, Yamada ES, Perry VH (2004) Morphology and physiology of primate M- and P-cells. Prog Brain Res 144:21-46.

Sterling P, Freed MA, Smith RG (1988) Architecture of rod and cone circuits to the On-beta ganglion cell. J Neurosci 8:623-642.

Sun H, Smithson HE, Zaidi Q, Lee BB (2006) Specificity of cone inputs to macaque retinal ganglion cells. J Neurophysiol 95:837-849.

Troy JB, Shou T (2002) The receptive fields of cat retinal ganglion cells in physiological and pathological states: where we are after half a century of research. Prog Retin Eye Res 21:263-302.

Tsukamoto Y, Masarachia P, Schein SJ, Sterling P (1992) Gap junctions between the pedicles of macaque foveal cones. Vision Res 32:1809-1815.

Wässle H (2004) Parallel processing in the mammalian retina. Nat Neurosci 5:747-757.

Wässle H, Boycott BB (1991) Functional architecture of the mammalian retina. Physiol Rev 71:447-480.

Wässle H, Grünert U, Rohrenbeck J, Boycott BB (1990) Retinal ganglion cell density and cortical magnification factor in the primate. Vision Res 30:1897-1911.

Wässle H, Grünert U, Martin PR, Boycott BB (1994) Immunocytochemical characterization and spatial distribution of midget bipolar cells in the macaque monkey retina. Vision Res 34:561-579.

Watson AB, Robson JG (1981) Discrimination at threshold: labelled detectors in human vision. Vision Res 21:1115-1122.

Williams DR (1986) Seeing through the photoreceptor mosaic. Trends Neurosci 9:193-198.

van Wyk M, Taylor WR, Vaney DI (2006) Local edge detectors: a substrate for fine spatial vision at low temporal frequencies in rabbit retina. J Neurosci 26:13250-13263.

Xu Y, Dhingra NK, Smith RG, Sterling P (2005) Sluggish and brisk ganglion cells detect contrast with similar sensitivity. J Neurophysiol 93:2388-2395.

Yamada ES, Bordt AS, Marshak DW (2005) Wide-field ganglion cells in macaque retinas. Vis Neurosci 22:383-393. 